\title{
Reviewing the Implementation of Maternal, Neonatal, and Child Health Services during the COVID-19 Pandemic in Indonesia
}

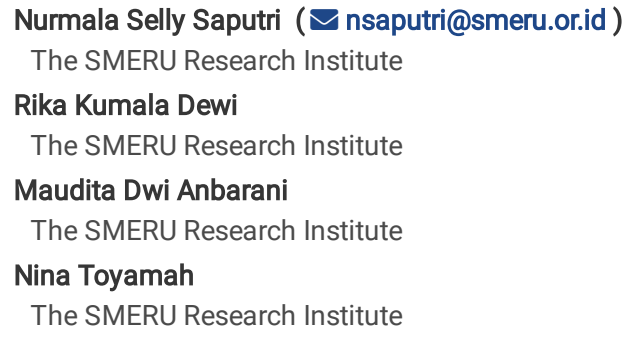

\section{Research Article}

Keywords: MNCH services, COVID-19 pandemic, Socio-ecological Model

Posted Date: February 7th, 2022

DOI: https://doi.org/10.21203/rs.3.rs-1215258/v1

License: () (1) This work is licensed under a Creative Commons Attribution 4.0 International License. Read Full License 


\section{Abstract}

\section{Background}

The COVID-19 pandemic has challenged the resilience of Maternal, Neonatal, and Child Health (MNCH) care in Indonesia. Mobility restriction policy and obligatory preventive measures practices could influence the service implementation. Previous literature suggested that communicable diseases outbreak brought fear and mistrust to the health system which resulted in the decrease of service coverage during emergency situations. As one of the world's worst-hit COVID-19 countries, Indonesia faces considerable challenges in maintaining health services, including MNCH care. This study investigated multi-level factors which become barriers to the implementation of $\mathrm{MNCH}$ care during the COVID-19 pandemic in Indonesia.

\section{Method}

Qualitative case study was conducted in three Kabupaten (districts), namely Sidoarjo, Gowa, and Manggarai Barat. The selection of these areas was based on the high COVID-19 cases and different achievements in $\mathrm{MNCH}$ indicators' coverages. Individual in-depth interviews were conducted with 133 people involved in $\mathrm{MNCH}$ services, such as women as the main users of the services, health workers, cadres, village representatives, as well as staff from local district health offices. Data were analyzed using the Socio-Ecological Model (SEM) Framework and constant comparative techniques to triangulate information among informants.

\section{Result}

A total of 133 people participated in the study, of which $67 \%$ were women who were pregnant, giving birth, or having children aged under-5 during the COVID19 pandemic. The factors that affect the utilization of $\mathrm{MNCH}$ services were categorized in five socio-ecological levels of analysis, namely individual factors (fear of COVID-19 contraction and awareness of the importance of $\mathrm{MNCH}$ services); interpersonal factors (unsupportive extended family and financial barriers); community-based factors (local norms and beliefs, limited transportation services, and geographical barriers), organizational factors (unequal distribution of health resources, ineffective implementation of preventive measures in the health facility, and impractical innovation of services approach), and policy (rapid development of guidelines and 'one size fits all' policy issues).

\section{Conclusions}

Fear of COVID-19 contraction and persistent barriers from multi-faceted factors had hindered the effective implementation of MNCH care during the COVID-19 pandemic in Indonesia. The Government of Indonesia, along with local governments, are required to develop specific solutions based on the capacity of health resources as well as interactive and multilevel factors which inhibit women's decision and practice to seek MNCH care in a volatile situation.

\section{Introduction}

Indonesia has sailed through a long journey to improve maternal, neonatal, and child health (MNCH) care in order to fulfil its commitment to the Sustainable Development Goals (SDGs). By 2030, every country is expected to have less than 12 neonatal deaths per 1,000 live births and 25 deaths per 1,000 live births for children under- 5 of age. Meanwhile, for the maternal mortality rate (MMR), it is expected that no country exceeds twice the global target of 70 maternal death per 100,000 live births [1]. According to the latest data available, Indonesia is still having much homework to reduce MMR as in 2017 there were 177 maternal deaths per 100,000 live births [2]. The situation for children's health is more improved as the data showed under-5 mortality and neonatal mortality rates were 23.9 per 1,000 live births and 12,9 per 1,000 live births, respectively [3, 4]. In a different indicator of child health, which is the prevalence of stunting, Indonesia sets an ambitious target to reduce stunting to $14 \%$ in 2024 , while the 2019 prevalence was around $27 \%$ [5]. Considerable efforts have to be implemented to achieve the targets.

Substantial increases in $\mathrm{MNCH}$ indicators have been taken place nationally however large gaps exist especially in rural areas and the Eastern Part of Indonesia. In 2019, some MNCH indicators' coverages have exceeded national targets, such as fourth antenatal care (ANC4+) (88.54\% vs target $80 \%$ ), institutional births ( $88.75 \%$ vs target $85 \%$ ), postnatal care (PNC) for newborn ( $94.9 \%$ vs target $90 \%$ ), and basic immunization services (93.7\% vs target $93 \%$ ) [6]. Nevertheless, further analysis to the regional level shows that some provinces' performances were lagged compared to other regions. For example, the prevalence of ANC4+, institutional births, and PNC in Papua (in Eastern Indonesia) were 37.5\%, 46.5\%, and 53.1\%, respectively.

Indonesia is home to around 270,000,000 people who are dispersed in nearly 12,000 liveable islands. Although there are five big main islands in Indonesia, about $56 \%$ of people lived on Java Island [7]. Most of the economic activities were centralized in Java Island, which automatically created an uneven development for other regions. Difficult geographical access, unequal distribution of health personnel and health facilities, high poverty rate, and low levels of education are some factors identified to cause large differences in $\mathrm{MNCH}$ performances among regions [8, 9]. Moreover, in 2020, Indonesia is facing a new challenge that deteriorates the low-capacity health system in many parts of the country.

Since early 2020, the world has been affected directly and indirectly by coronavirus disease (COVID-19), no exception for Indonesia. Indonesia declared its first corona cases in March 2020, and since then some restrictions have been implemented to control coronavirus transmission [10]. As COVID-19 cases continued to increase significantly, the Government of Indonesia (Gol) and the local government stipulated Large-Scale Social Restriction Policy (PSBB) in April 2020 and the Policy for Enforcement of Restrictions on Community Activities (PPKM) in February 2021 [11]. The increases in COVID-19 cases and the restriction were, directly and indirectly, disrupted many sectors, including the health system, economy, industry, as well as education system.

The indirect impact of the COVID-19 pandemic for the health sector is the difficulty to maintain and sustain essential health services, such as MNCH services. Communicable diseases outbreak effects to $\mathrm{MNCH}$ services have been recorded since the Ebola crisis in 2014 [12, 13]. The studies reported that during the 
Ebola outbreak, some $\mathrm{MNCH}$ services trend decreased, such as institutional births, antenatal care visits, and child vaccination. With higher cases around the world, COVID-19 might have a bigger impact on MNCH services. Moreover, due to the inequality of health resources across Indonesia, the impact of the COVID19 pandemic can be worse for areas with limited health resources. To date, there is limited knowledge of the COVID-19 effect on MNCH services, especially in developing countries. Therefore, this study aimed to explore barriers and opportunities of women in Indonesia to access MNCH services during the COVID-19 pandemic.

The main objective of this study is to identify the challenges to $\mathrm{MNCH}$ services that arise during the pandemic. The MNCH indicators which will be reviewed through this article include ANC, institutional birth, PNC, neonatal care, monthly weighing for children aged under-5, and basic immunization services. We will compare the implementation of the services in the previous year before the pandemic using available data as well as explore the barriers which hinder women and children in accessing the services.

\section{Methods Study design and settings}

The study was conducted in three districts in Indonesia namely Kabupaten Sidoarjo, Kabupaten Gowa, and Kabupaten Manggarai Barat in February-April 2021. The selection of the districts was based on the number of cases of COVID-19 throughout 2020, the ratio of public health center (Puskesmas) per 1000 population, as well as $\mathrm{MNCH}$ outcomes such as MMR, neonatal mortality rate, and under-5 mortality rate. For the MNCH indicators, we used 2017 data which was the latest data available and comparable across provinces.

To better capture policies and initiatives related to the continuity of $\mathrm{MNCH}$ services during the pandemic, we purposively select districts with high COVID-19. During 2020, Sidoarjo, Gowa, and Manggarai Barat were among districts with highest COVID-19 cases in each respective provinces (Jawa Tengah, Sulawesi Selatan, and Nusa Tenggara Timur). In April 2020, PSBB was already conducted in In Sidoarjo and Gowa, which then affected the implementation of health services. Meanwhile, in Manggarai Barat, PSBB was not yet conducted but the declaration of red zone status (meaning high cases of COVID-19) in May 2020 [14] also influenced the sustainability of essential health services.

To understand the differences in $\mathrm{MNCH}$ services resiliency during the pandemic, we utilized health system capacity as an indicator to select the districts. The health resources were depicted by the ratio of Puskesmas per 1000 population and $\mathrm{MNCH}$ outcomes in 2017. Using those indicators, thus, Sidoarjo reflects an area that has a wide availability of health facilities and relatively low MMR, neonatal mortality, and under-5 mortality compared to other districts in the same province. Gowa reflects a good ratio of Puskesmas per 1000 population, but it had a high number of maternal mortality rates compared to other districts in the same provinces. Whereas Manggarai Barat reflects a district with a limited number of health facilities available and had a high number of MMR, neonatal, and child death in 2017.

\section{Informants' recruitment}

This study used the snowball sampling technique to find prospective informants in subdistricts and villages levels. In each district, the first interview was conducted with District Health Office (DHO) so that we could understand the MNCH situation. After that, we asked the DOH's staff to recommend two subdistricts as well as provided us with phone contacts of local health workers to be interviewed. The selection of subdistricts was based on their distance from the city center or the challenging situations about access to $\mathrm{MNCH}$ services (Figure 1).

At the village level, the cadres assisted us to gain every name and phone contact of women as our prospective informants. The criteria for women were, among others, pregnant women, newborn mothers, and women with children aged under 5 . In total, there were 90 women interviewed in this study. We also included private health workers and health workers from hospitals to get more information about MNCH services utilization during the pandemic.

\section{Data collection}

All interviews were conducted using telephone or WhatsApp Calls due to an increase in COVID-19 cases in Indonesia during the data collection process. The interviews followed semi-structured in-depth interview guides that were differentiated by the type of informants (women, cadres, community figures, health workers, and DHO's staff). Similar themes were used in all interview guides to allow theme analysis across informants. We recruited three research assistants (RA) who were fluent in each local language to ensure no language barriers during the interview. The RAs were trained for one-day prior data collection process to ensure their understanding of the topics and all interview guidelines. They also were involved in creating field notes and transcripts. All interviews were recorded with consent. All informed consents were read to informants before the interview started.

\section{Interview guidelines}

Semi-structured interview guidelines were created for each type of informants. Generally, the structure of the guidelines consisted of (i) informants' knowledge of COVID-19 situation in their living areas, (ii) implementation of $\mathrm{MNCH}$ services before and during the pandemic, (iii) barriers that hinder the implementation of the services, (iv) COVID-19 risks perception, and (v) strategies to implement the services during the pandemic. For DHO's staff, health workers, and community figures we had additional questions about policies related to the prevention of COVID-19 spread as well as changes in MNCH services during the pandemic. Whereas for women, we had separate questions' set for expectant women, newborn mothers, and women with children aged under-5.

\section{Theoretical Framework}

To deeply capture the barriers to accessing the services, we used Socio-ecological Model (SEM) as our framework. The SEM was used to guide the interview process as well as to analyze the research findings. By using SEM, one can investigate the interactive process of multilevel factors which influence the wellbeing of a population and its decisions to access health services $[15,16]$. Figure 2 shows elements from each stage of SEM. 
Overall, we adopted five stages of SEM to understand barriers and supports that women face and received to access the services. Individual factors mainly concerned personal knowledge and awareness about MNCH services, risk perception about the pandemic, as well as health conditions that affect women's decisions and attitudes towards health services. In interpersonal factors, we tried to explore women's relationships with their families and family values about accessing $\mathrm{MNCH}$ services. In this factor, we also capture the socio-economic condition of the family and the change they were going through during the pandemic. For community factors, we explore any norms or cultures which inhibit women to conduct healthy behaviors during their motherhood journeys in raising their children. Any infrastructural barriers in neighborhoods are also part of the community factors. Organizational factors mean health facilities and their availability to conduct the services. Lastly, policy factors include regulations, programs, or guidelines that are related to COVID-19 as well as the implementation of the $\mathrm{MNCH}$ services.

\section{Data analysis}

An analysis was performed using a thematic analytical approach by using five levels of SEM and differentiated by the type of MNCH services (pregnancy, childbirth, neonatal and postnatal services, immunization, vitamin A capsule distribution, and child growth monitoring). At the start, the interviews were transcribed by the RAs. The main researchers responsible for each area read the transcripts repeatedly to gain familiarity with the contents. Any confusion in the transcripts will be confirmed by listening to the original interviews' recordings and discussing them with the transcripts' authors. For each MNCH indicator, the researcher will code findings to five levels of SEM (individual factors, interpersonal factors, community factors, organizational factors, and policy factors). The coding process was done using Microsoft Excel. Any discrepancies during the coding process will be discussed and reconciled in a weekly meeting. The produced matrix helps the researchers to explore data by theme and respondent types. To gain further understanding of changes in $\mathrm{MNCH}$ services during the pandemic, a root causes analysis was done by diagnosing the pathway of certain problems.

Preliminary findings from the study were presented in a focus group discussion (FGD) in each study location. The FGD was attended by local stakeholders and health workers representatives from Puskesmas and hospitals. During the FGD, the participants gave feedback on the research findings as part of data triangulation. The inputs from the meeting were used to improve the research findings, especially to sharpen the recommendations.

\section{Results}

\section{Informants' characteristics}

In total, we conducted 133 in-depth interviews which consisted of mainly 6 types of informants. Table 1 shows the number of informants for each category. Most of our informants were women that distributed as follows: 30 in Sidoarjo, 31 in Gowa, and 29 in Manggarai Barat. We also interviewed 23 health workers, 9 village leaders, and 6 cadres. The number of village leaders is different in each region because in Gowa we interviewed a newly appointed village leader[1] and his staff who has worked at the village longer to better capture the barriers of MNCH services before and during the pandemic. Meanwhile, in Manggarai Barat, we added one more village on a small island, near the main island, to depict the issues of accessing MNCH services for women who lived on the island.

Table 1

Number of informants in qualitative interviews

\begin{tabular}{|lllll|}
\hline Type of informant & Sidoarjo & Gowa & Manggarai Barat & Total \\
\hline Women & 30 & 31 & 29 & 90 \\
\hline DHO's staffs & 1 & 2 & 1 & 4 \\
\hline Health workers & 7 & 8 & 8 & 23 \\
\hline Cadres & 2 & 2 & 2 & 6 \\
\hline Village leaders & 2 & 4 & 3 & 9 \\
\hline Other district government & 0 & 0 & 1 & 2 \\
\hline Total & $\mathbf{4 2}$ & $\mathbf{4 7}$ & $\mathbf{4 4}$ & $\mathbf{1 3 3}$ \\
\hline
\end{tabular}

Table 2 shows the characteristics of the women who participate in the qualitative study. The mean age of participants is approximately 29 years old. Based on educational background, all women had finished, at least, elementary school, mostly finished secondary education (41.1\%), and had a higher educational background (22.2\%). More than half of the women (62\%) were not working (housewife).

Table 2

\section{Characteristics of Women in Qualitative Method}




\begin{tabular}{llc} 
Variables & Frequency & (\%) \\
\hline District & & \\
\hline Sidoarjo & 30 & 33.3 \\
\hline Gowa & 31 & 34.4 \\
\hline Manggarai Barat & 29 & 32.3 \\
\hline Mean of age & $29.1(95 \%$ Cl: $27.9-30.2)$ \\
\hline Educational background & & \\
\hline Elementary education & 16 & 17.8 \\
\hline Primary education & 17 & 18.9 \\
\hline Secondary education & 37 & 41.1 \\
\hline Higher education & 20 & 22.2 \\
\hline Working status & & \\
\hline Yes & 34 & 37.8 \\
\hline No & 56 & 62.2
\end{tabular}

\section{Continuity of MNCH services during the COVID-19 pandemic}

In general, all three districts experienced a drop in MNCH services, especially in the first three months (April-June 2020) of the COVID-19 pandemic in Indonesia. Almost in all MNCH indicators, the visits in 2020 were lower than in the year 2019, except for antenatal care visits in Gowa which increased from July to September 2020 (Figure 3). Unlike Gowa and Manggarai Barat, the decrease in MNCH visits in Sidoarjo was more stagnant across the year. Meanwhile, in Manggarai Barat and Gowa, a steeper reduction was more clearly seen in some indicators, such as in antenatal care, postnatal care, and institutional births. These resulted in the increase of non-institutional childbirths, especially those assisted by traditional birth attendants (TBAs). The distribution of vitamin $A$ supplementation for children aged under-5 did not undergo marked change in August 2020 as most services have been re-conducted, especially in areas with lower COVID-19 cases. To explain the factors which causes the decrease, as well as the, bounced back of MNCH services during the year 2020 , we follow SEM's five stages of factors.

\section{INDIVIDUAL FACTORS}

\section{Fear of COVID-19}

Many informants reported that the decrease in the MNCH care-seeking behaviors during the pandemic was caused by the fear of COVID-19. Some MNCH services that women preferred to delay among others, immediate first antenatal care, blood testing or ultrasonography (USG), removing stitches after childbirth or monitoring the growth (weight and health) of their children. Some women are worried to visit health facilities especially when they need to bring their newborn babies for neonatal care visits. On the other hand, health workers admitted the difficulties of increasing women's willingness to visit health facilities even after promising to give food for incentives.

"The fear of visiting health facilities is still a lot. Many pregnant women... start in July, and August [2020] came to health facilities when their pregnancies already above the age of the first trimester." (Health Workers, 34 years old, Manggarai Barat).

"From January to December 2020, from 472 pregnant women, we found 18 women who delivered their babies at home assisted by TBA. This situation was caused by [women's] fear of contracting COVID-19, thus they did not go to health workers [to deliver baby]." (Health Workers, 34 years old, Manggarai Barat).

"I needed more time to think when [midwife asked] I had to go to Labuan Bajo [a city across the island] to get my USG test because I am afraid of corona." (Pregnant Women, 28 years old, Manggarai Barat).

"...yes [my baby did not have neonatal care visit in his first month] because I was afraid. Because [my baby] was still too young at that time, and we need to travel far [to health facility] ... around $1 \mathrm{~km}$ from my home to Posyandu (integrated health service post) ... yes, by foot." (Newborn Mother, 21 years old, Gowa).

"I didn't go [to Puskesmas], Mam... I am afraid of the corona. I do not want to go to Puskesmas. I am afraid to go there [health facility]." (Women with children aged under-5, 21 years old, Sidoarjo).

We found that there are three types of fears that women experiences during the pandemic. The first one is the fear of contracting the virus during the visits to health facilities or health workers. The second one is the fear of having tested positive for COVID-19 and the need to have self-isolation. The last one is the fear of hoax, such as fear of vaccines for basic immunization containing the coronavirus. These three types of fears indirectly cause a decline in $\mathrm{MNCH}$ services. 
To prevent the spread of coronavirus, some local governments introduce new policies, such as increasing COVID-19 test coverage for high-risk populations, including pregnant women. In Sidoarjo, all expectant women are required to get COVID-19 Polymerase Chain Reaction (PCR) test two weeks before the estimated day of birth. Meanwhile, in Gowa, some hospitals require every pregnant woman to have Antigen Test before labor. The testing policy actually aims to prepare appropriate facilities when the women face a complicated delivery due to COVID-19. Based on the national guideline, all positively tested pregnant women will be referred to a designated COVID-19 hospital before the labor. Moreover, by referring the women to the designated hospital, it will minimize the risks to health staff in non-COVID-19 health facilities.

However, due to incomplete awareness about the importance of the test and misconceptions about the cause of positive results in the test, many women refused to get tested. They are worried about being separated from their newborn babies if they were tested positive. Moreover, due to misconceptions of COVID-19 contraction, some women think that pregnancy can cause a positive result in the COVID-19 test. Others who do not understand the importance of the test usually think that additional COVID-19 test procedure is troublesome. Some women reject the tests. Meanwhile, those who were tested positive would search for other health facilities and speak untruthfully about their COVID-19 status so that they would not have to deliver their babies in the designated hospitals.

"[I found] sometimes [misinformation about pregnancy and covid-19] is very identical among patients, especially when the patient got positive COVID-19 result. It feels like they think 'I am COVID-19 positive because I am pregnant'. Well, I am actually confused with the way they think... like where do they get that kind of information?" (Health workers, 38 years old, Sidoarjo).

"I don't want to get the swab test. [I think] it's burdensome." (Pregnant women, 38 years old, Sidoarjo).

\section{Lack of knowledge of the importance of $\mathrm{MNCH}$ services}

Apart from being afraid of the coronavirus, we found some women had a lack of knowledge and awareness about the urgency of seeking health services. Some pregnant women deliberately delayed starting their antenatal check-ups and even planned to give birth assisted by TBA. We also found that women with limited understanding of child-rearing will stop monitoring their children's growth in Posyandu once they finished basic child immunization. While some children also had incomplete or delayed immunization.

Inadequate understanding of maternal care is caused by many factors. Lack of educational background, and minimum socialization from health workers, as well as relevant experiences from previous pregnancy and childbirth, are three factors that we found in this research. Women are more likely to continue home delivery and use TBA because in previous childbirth they did not encounter any problems. Such experiences grow a belief that home delivery is as safe as institutional childbirth. Moreover, the availability of TBAs in some areas in Gowa and Manggarai Barat cannot eliminate the demand for TBAs for pregnant women.

"Those women [who had good experiences giving birth assisted by TBA] think that delivering a baby is a normal process. When they had a normal vaginal birth in the previous childbirth, they tend to think that the next childbirth will also be a normal process. Meanwhile, [we know] postpartum haemorrhage sometimes could not be detected solely by USG result." (Health worker, Manggarai Barat).

In Manggarai Barat, we also found that late antenatal check-up was caused by unknown pregnancy. Several women reported that they got multiple negative results from the pregnancy test kits until they realized they were pregnant. Some of them even came to health facilities (with unknown pregnancies) to check their condition but only to be diagnosed as having an ulcer problem. Due to this problem, they were late having appropriate antenatal care from the beginning of the pregnancy.

"This is an unknown pregnancy. Suddenly I have nausea and vomiting. I think I have ulcer disease. I took medicine, I went to the midwife. Because I did pregnancy tests 3 to 4 times, and the results weren't positive but negative. That's why I said to the midwife that I was not pregnant. I had an ulcer. Finally, the midwife gave me medicine [for ulcer]." (Newborn Mother, 36 years old, Manggarai Barat).

\section{Growing awareness of maternal and child health services}

Despite the reduction of $\mathrm{MNCH}$ visits during the pandemic, we also found that some of the women still went to health services. In Figure 4, many $\mathrm{MNCH}$ indicators, such as antenatal care in Gowa and Sidoarjo, rose back around July-September 2020. These increases show that some women had keen awareness about the importance of MNCH care-seeking behaviors even though they also fear COVID-19. Moreover, in Sidoarjo, we found that several women visited health facilities more than one time in a month as if it was not a pandemic situation. These behaviors were influenced by many factors, such as bad experience from previous miscarriages, willingness to see their infant through USG, getting forced by midwives (only in Manggarai Barat), and their increasing awareness because they actively look for information about MNCH services.

"[yes, I am] afraid of COVID-19. In the early pregnancy, ... I did not go anywhere even to my parent's house.... [But] I still went to Puskesmas [to check my pregnancy]. It is important for the health of the mother and the baby." (Pregnant women, 32 years old, Manggarai Barat).

"Praise to God, no barrier [in accessing antenatal care in a health facility during the pandemic]. Yes, I'm afraid [of COVID-19, but I keep my body healthy, stay alert [to COVID-19], and eat healthy meals which contain many vitamins." (Pregnant women, 23 years old, Gowa).

"Twice in a month [having antenatal cares]. I did USG [in the hospital], and [I did antenatal care] in Puskesmas. If my vitamin from my [hospital] doctor run out, then I will consume the one from Puskesmas." (Pregnant women, 28 years old, Sidoarjo). 
To safely visit MNCH services providers, women will take preventive measures against COVID-19 (wearing a mask, maintaining a safe distance, and handwashing) for themselves and their children. Some women also prefer to check any problems during their pregnancy by using online antenatal care. For the children, some mothers routinely weigh their children individually and report the results to health workers or cadres.

"Yes [afraid] but [going to health facility] not that horrible compared to when I visit public places. In Puskesmas, InsyaAllah [God willing] the preventive measures are well implemented..." (Pregnant women, 31 years old, Sidoarjo).

"During the pandemic, I did not seek for any antenatal care. But coincidentally, my uncle's wife works in Hospital X as a nurse in MNCH services. Thus, I had my [online] pregnancy consultation with her." (Pregnant women, 35 years old, Sidoarjo).

\section{INTERPERSONAL FACTORS}

\section{Fear of COVID-19 in family level}

Woman's decision to seek health services is often influenced by their family members, including husbands and the elderly. In Gowa and Manggarai Barat, we found strong family influences affecting woman's care-seeking behavior. During the COVID-19 pandemic, family members often forbid women to visit health facilities due to fear of coronavirus contraction or fear of the women being intentionally misdiagnosed as COVID-19 positive. The latter issue was very common among our informants. This had caused many women to prefer to delay seeking health care.

"My family said that if I feel sick, I should go to pharmacy [to buy unprescribed medicine] rather than go to the hospital. [They said] if I go to the hospital to check my flu, I could be diagnosed having COVID-19. So, I just went to pharmacy." (Pregnant women, 27 years old, Manggarai Barat).

\section{Unsupportive and (sometimes) unnecessary support from family}

Misconception about MNCH care at the family level could cause women to delay in seeking health care. For example, in Manggarai Barat and Gowa, some babies did not receive their basic immunization because grandmothers feel sorry to have their grandson injected. Also, some fathers did not want their child to suffer from high fever and cry overnight after the immunization. In case of childbirth, many elderlies do not allow women to give birth in the health facility and recommend the TBA instead. Another example is family members forcing a mother to bring her baby home because they feel that the baby was hospitalized for a long time. In the latter case, the baby was a high-risk newborn.

On the other hand, we also found some families give unnecessary supports which creates a financial burden for women. In some areas of Indonesia, there is a local culture where family members or relatives should accompany the expectant women to health facilities to do check-ups or to deliver the babies. Although it senses positive support, sometimes women find this attitude burdensome because in some cases women need to bear every transportation and accommodation costs for all people who accompany her to the health facility.

"II] spent a lot of money to go to Labuan Bajo [a city across the island]. My family accompanied me to Labuan Bajo. [Since we need to spend a night there] so I and my husband have to pay the hotel, meals, fuel." (Newborn mother, 36 years old, Manggarai Barat).

\section{Financial barriers}

Uneven distribution of health facilities in Indonesia causes some women to spend more money to access health facilities. In Gowa and Manggarai Barat, unavailability of medical tools (USG device, laboratory, blood test tool) in some providers force women to access a farther health facility which costs more money. Some women cannot afford the medical as well as transportation cost to access these services due to financial situations during the pandemic or they were run out of money for delivering their babies.

"She [the midwife] told me to get a USG test in the private clinic but I have not done it yet because I do not have enough money." (Pregnant woman, 30 years old, Manggarai Barat).

"I usually need to think over it [if I need to visit midwife]. I need to collect more money first so that I can go to the midwife. [It is different from the old times] When I was sick, I immediately went to Puskesmas. Now, because I need to pay, I need to collect and set aside the money." (Pregnant women, 35 years old, Gowa).

"I lend money from others to pay for my antenatal care and USG test." (Pregnant woman, 27 years old, Manggarai Barat).

To solve the financial burden to access health services, Indonesia has actually enacted a National Health Insurance program namely JKN since 2014 however many people are still not covered by this program. JKN program is social health insurance that covers most of the medical conditions, including maternal and child health care needs. JKN also covers essential MNCH services, such as antenatal care, USG test (prescription from health workers is required), delivery in health services, up to neonatal care, and child immunization. However, to date, only $83.5 \%$ population are already covered in the program. Thus, $16.5 \%$ of the population is still at risk of having difficulties in accessing health services due to financial problems. Moreover, JKN has not yet solved the access issues as it does not cover the non-medical out-of-pocket payment such as transportation costs or accommodation costs. BPJS Kesehatan (Health care and Social Security Agency) also has not yet in partnership with all available health facilities in Indonesia which causes limited health facility choices for its members in some remote areas. Hence, financial problems are still a barrier for women in accessing health care.

Page 7/17 


\section{COMMUNITY FACTORS}

\section{Socio-cultural barriers}

Various places in Indonesia still hold beliefs that are brought over years and become part of the culture. Several norms were found in all research areas however local cultures that hinder care-seeking behaviors are solely observed in Gowa and Manggarai Barat. For example, we found myths about prohibition for young infants aged less than 40 days old and postpartum women to go out of the house. These beliefs hinder babies and new mothers to get their neonatal as well as postpartum checks. Another prohibition involves pregnant women where they are forbidden to cross the sea when pregnant which could delay the antenatal care services. We also found a prohibition for women to consume certain types of food, mainly vegetables, and fruits, during pregnancy and postpartum periods.

"I believe that before 40 days, a baby should not go out from the house. My mother told me that." (Newborn mother, 26 years old, Gowa).

\section{Transportation and geographical barriers}

Limited types of public transportation services, damaged roads, and weather problems still affect the sustainability of MNCH services, especially in Gowa and Manggarai Barat. Meanwhile, in Sidoarjo, some women do need more travel time to health facilities, but most areas are relatively accessible. In Gowa and Manggarai Barat, some areas can be solely accessed by foot especially during the rainy season. Sometimes pregnant women need to be carried on a stretcher on foot to reach the main road and use the rented car to access the health facility.

"It takes probably one hour [to reach Puskesmas]. Mrs. X is the one who has the initiative to take pregnant women to Puskesmas. She has told [the people in the village] that any woman who's pregnant or about to give birth and wants to go to Puskesmas, should notify her first. Mrs. X (a cadre) will then take the women to Puskesmas. She has prepared a stretcher in the village to take pregnant women to the main road [where Puskesmas is located]." (Health workers, 53 years old, Gowa).

"Pregnant women who about to give birth was carried on a stretcher called 'Lemba' by husband and male family members. Sometimes, the mother gave a birth before we reach the health facilities." (Cadre, 43 years old, Manggarai Barat).

\section{ORGANIZATIONAL FACTORS (HEALTH SERVICES)}

\section{Uneven distribution of health facilities and health workers}

The COVID-19 pandemic not only affects health-seeking behaviors of the women but also affects the availability of health facilities. MNCH services providers often limit the operating hours or close the facility, especially the private providers, due to an increase in COVID-19 infections among patients and health staff. The closure of a health facility automatically reduces the number of available providers, especially in remote areas where the health facility is limited.

The pandemic impact on the closure of health facilities gives considerable effects for women in Gowa and Manggarai Barat. Figure 4 shows that the number of Puskesmas across districts is not very varied, however, the number of hospitals and private midwives, and clinics are very different. Among our three study areas, an adequate number of health facilities and health staff is solely available in Sidoarjo. Thus, despite the closures of many health facilities, women in Sidoarjo still have the flexibility to choose other providers based on their needs (closer distance, quieter providers, quieter time, and comfortability). In Sidoarjo, there are 26 hospitals and 340 private midwives and clinics available, meanwhile, in Gowa and Manggarai Barat, the number of small and private clinics is very scarce. Moreover, in Manggarai Barat, we do not find any data on the number of private midwives at all. The Gol has a major initiative to assign, at least, a midwife post in each village in rural Indonesia. However, the designated midwife is often unavailable in the posts. In addition, most of the midwife post has infrastructure limitation where women cannot give birth there. Hence, apart from the government health facilities, women in Manggarai Barat solely have limited choices of $\mathrm{MNCH}$ services providers.

"Of course, I am worried [about COVID-19] ... I want to go out from my house, but I am afraid. In the end, I prefer to visit the nearest midwife [to have antenatal check]." (Pregnant woman, 26 years old, Sidoarjo).

"... when the Government implemented the Large-Scale Social Restriction (PSBB), my friends told me that my frequently visited clinic was closed while I know many women planned to give birth there... At that time, I was confused. Moreover, I was already in my third trimester, but many clinics and midwives were closed. Then... in the last minute, I chose to give birth at a hospital." (Pregnant woman, 35 years old, Sidoarjo).

The implementation of restriction policy also affected the operation of Posyandu. As the frontline of health services in most of the communities in Indonesia, the closure of Posyandu is directly associated with the decrease in monthly child growth monitoring as well as basic child immunization coverage. Even though in August 2020 many Posyandu had already re-opened its services, especially those located in safe COVID-19 zones, many women were worried to bring their children to Posyandu due to fear of COVID-19.

"In the early month of the COVID-19 pandemic, starting from March, Posyandu was closed until April 2020. In May, we open the Posyandu again, but not many people came." (Health workers, 50 years old, Manggarai Barat). 
In addition to the uneven distribution of health facilities, the shortage number of health workers is also a problem during the COVID-19 pandemic. In all districts, we also found that the increasing burden for health workers during the pandemic, especially duties related to COVID-19. Sometimes, when there are health workers who need to have COVID-19 quarantine, other staffs need to carry out their tasks.

"II think] we have enough of health workers, but their tasks are increasing. Now, they need to trace the COVID-19 patients too... One time I worked until midnight in the cemetery [to monitor burial process of COVID-19 patient." (Health workers, unknown age, Sidoarjo).

\section{The implementation of preventive measures at the health facility}

In general, our informants considered the implementation of preventive measures in health facilities were effective. The preventive measure applicated in health facilities includes limiting the working hours of health workers, limiting contact time with patients, maintaining distance among patients and staff, temperature screening in the entrance, online appointments before coming to the facility, Personal Protective Equipment (PPE) usage for all staffs and visitors, and providing handwashing facilities. At the beginning of the COVID-19 pandemic, all people were also urged to stay at home and to visit health facilities only in an emergency situation.

Despite most of the informants considered a good practice of preventive measures in health facilities, some others think that health facilities still face many challenges. In Sidoarjo, MNCH's health staff claimed that they need to buy their masks due to the limited availability of standard PPE in Puskesmas. However, they usually purchased cloth masks, which are not recommended for health workers because they put health workers at high risk of COVID-19 infection. Moreover, in Manggarai Barat, the unavailability of PPEs made the health workers use nothing which was against the standard procedures when serving the patients during the pandemic. Meanwhile, from the patient's side, some informants reported that many people were still not aware of wearing masks before going out of their houses. In Sidoarjo, people who were not wearing a mask when visiting health providers were prohibited from entering the facility. On the other hand, in Manggarai Barat, such prohibition could not be implemented as there was a limited number of masks are available. Also, if the health workers expel the patients due to mask's problem, the patients will not come to the health facility which will reduce access to the health facility in general.

"The stock of PPE clothing ... is sufficient ... what often experiences shortages are masks and gloves." (Health Worker, Manggarai Barat).

The preventive measure implementation in Posyandu was even worse. The national guideline urges that the cloths used for traditional child's weighing tools should be disinfected in every weighing process. However, many health workers did not implement the procedure is burdensome as they need to be calibrated the scale after every use. In Manggarai Barat, limited masks and water make it difficult to implement the measures. Health workers cannot ask people to leave and return home to wear masks because their homes are far away from Posyandu.

"Clean water source is far away. We have been overwhelmed with the supply of clean water for fulfilling health workers' needs, as well as for hand washing activities [during posyandu].... Many mothers do not wash their hands at the posyandu." (Health workers, unknown age, Manggarai Barat).

\section{Availability of Medicine, Vitamins, Vaccines}

We found that there was a disruption to the distribution of medicines and vitamins for MNCH care during the COVID-19 pandemic, but more of the problems have occurred before the pandemic. In Gowa, some types of medicines, such as Oxytocin and Magnesium Sulfate, were available in limited quantities before the pandemic which resulted in a shortage of stock of medicines distributed by the DHOs to the Puskesmas. Even though Puskesmas could purchase these medicines independently, the lack of budget and availability of those medicines created a challenging situation for health workers in Puskesmas. In addition, the $\mathrm{MNCH}$ handbooks for women have been run out from before the pandemic. Hence, health workers had to provide a colorless, photocopy version for women. Sometimes, this could provide a challenge for women in reading the handbook since the black and white picture is usually less clear. In Manggarai Barat, the quality of the available test packs was poor, causing errors in pregnancy detection. Another problem was the medical tools, such as blood test kits, oxygen cylinders, cooler boxes for vaccines, were not always available at health facilities.

"Before the pandemic, there was a shortage in medicines, especially the ones we need during an emergency. When the pandemic hit us, the medicine shortage such as oxy [oxytocin] is even worse. We need to buy some of the medicine by ourselves. The shortage occurs because there is no stock in DHO." (Health workers, 32 years old, Gowa).

Meanwhile, in Sidoarjo, the shortage of medical equipment was not found however there was a problem with the reagents for PCR test. The policy regarding PCR provision for the vulnerable population was not supported by the availability of reagents. The high demand for PCR tests during the first year of the pandemic created a long queue in processing the tests. Some pregnant women complained that their test results were late due to the unavailability of reagents and the high demand for the test. Hence, sometimes the pregnant women have been referred to a hospital without bringing any COVID-19 test results.

"First it's a test... What's it called? Antigen test? Because the test at the Puskesmas did not come out for more than two weeks..." (Newborn Mother, 29 years old, Sidoarjo).

\section{Type of services}

To maintain the MNCH services during the pandemic, health workers create service modifications for women and children. They could conduct a face-to-face service, home visit, or an online consultation. However, these services have their drawbacks which resulted in an ineffective implementation. Face-to-face 
service is usually carried out in all health facilities for all types of $\mathrm{MNCH}$ services. However, because of limited visiting hours, a face-to-face consultation was sometimes sub optimally implemented and aimed to solely fulfill the administrative purposes. Moreover, women were relatively afraid to visit health facilities because of high COVID-19 contraction.

Some initiatives emerged due to limited service in health facilities, including a home visit by health workers and cadres. We found that home visits were primarily aimed at high-risk pregnant women and babies, as well as children with severe malnutrition. However, in some cases, home visits were also conducted for normal patients. During the discussion with the health workers, they realized that they have not yet had clear procedures regarding monthly targets and a clear schedule of home visits. In addition, not all health workers claimed able to conduct the visits, especially with the limited number of personnel in Puskesmas.

"April, May, June 2020 we had National Weighing Program for malnourished children. We visited babies' homes to give them immunizations because we have the data [about children's immunization status]. So, we made efforts to ensure no late immunization for the children. When we visited the baby for immunization, we sometimes also visited the malnourished." (Cadre, 30 years old, Sidoarjo).

“... [Our Puskesmas] has solely one nutritionist. Well, actually there are two but only one person is actively working." (Health workers, 46 years old, Sidoarjo).

Another initiative is conducting an online consultation, but, again, no clear protocols have been written on implementing a quality online consultation during the pandemic. We found that health workers provided ineffective online consultations for their patients. The online consultation services in all districts have not yet included all women, either because of lack of knowledge of the women about the services or women were reluctant to utilize the services. Some mothers revealed that they did not feel comfortable enough using the online services and preferred to visit the facility.

"...If you are pregnant, there is no group, WA, or anything [online consultation]. We have to actively ask for information from the midwife. Because if not, we will not know [the condition of pregnancy]." (Pregnant women, 28 years old, Sidoarjo).

"[During the pandemic], no remote services were carried out. The midwife actually gave me her cellphone number to me. The midwife suggested I to have a call when there is a health problem. But I still have to go to the Pustu to do an examination." (Newborn mother, 25 years old, Manggarai Barat)

"[I] Never have an online consultation. [I] find remote consultation is a bit challenging.. It is better to have face-to-face talk [with health worker]." (Pregnant women, 37 years old, Manggarai Barat).

\section{POLICY FACTORS}

Since the beginning of the pandemic, the Ministry of Health has issued various guidelines to ensure the continuation of MNCH health services. We found, at least, three handbooks are used to guide the implementation of $\mathrm{MNCH}$ services in health facilities. The creation of the handbook enables local health workers to continue carrying out safe $\mathrm{MCH}$ services. Based on the interviews, all health workers admitted that they had already received guidelines to safely implement the $\mathrm{MNCH}$ services.

DHOs and health workers reported that they received the socialization of the protocols online, such as via zoom meetings. The socialization was usually held several times. Firstly, the Ministry of Health will invite provincial health offices, district health offices, and Puskesmas head. Secondly, the district health offices will conduct a similar zoom meeting by inviting Puskesmas head and health workers. To ensure that all health workers received the information, the documents of protocols will be distributed through Puskesmas's WhatsApp groups. This communication method was considered effective in rapidly distributing information, especially during an emergency situation.

Nevertheless, we found that Puskesmas and health workers could not effectively implement the services procedures that are written in the protocols. From the supply side, for example, the protocols encourage the implementation of monthly Posyandu services for the community in safe COVID-19 zones to ensure the continuation of $\mathrm{MNCH}$ services, especially the basic immunization for children. However, the health workers admitted that such a procedure was difficult to be implemented due to rapid change in COVID-19 cases as well as the shortage of health workers. Similar reasons also occurred on home visits' services.

"We are encouraged to implement Posyandu based on the COVID-19 zone status. For example, in a green zone (low COVID-19 cases) we can do Posyandu along with some preventive measures. [However] the zone status is constantly changing so it is very difficult to achieve our targets." (Health worker, 46 years old, Sidoarjo).

From the demand side, women and families are expected to independently monitor their family's health during the pandemic. For mothers, it is expected that they conduct self-weighing on their children using a personal scale. Women are also encouraged to increase their own knowledge by reading the $\mathrm{MNCH}$ handbooks. However, unavailability of personal scale and low willingness to read MNCH's handbook were found during this research. Moreover, in many cases, the $\mathrm{MNCH}$ handbooks were kept by the cadres/village midwives to ensure that they would not lose. Also, not all mothers were found to have strong desires to read their $\mathrm{MNCH}$ handbook. Some admitted that they were too busy to read, some have difficulty in understanding the handbook, and others were simply illiterate.

"I rarely read it... [the MNCH Handbook]." (Women with children aged under-5, 33 years old, Sidoarjo).

"... [the content of the MNCH Handbook] some are difficult to understand, some are easy. Actually, I don't really read that book." (Newborn mother, 23 years old, Sidoarjo). 
Several other policies such as large-scale social restriction and budget tightening during the pandemic also affect the sustainability of MNCH services. Due to the social restriction policy, the health workers could not implement some $\mathrm{MNCH}$ programs, especially ones that involve a large number of people.

Socialization programs for the community, such as pregnancy class or stunting socialization programs had been stopped during the pandemic resulting in a reduction of knowledge distributions. In addition, the budget reduction policy affected the supplementary feeding supplies for malnourished children. To tackle this issue, several villages had initiatives to hold supplementary feeding programs by using collective funds from the community.

"Sometimes, if the midwife has some funds, she will ask cadres to cook mung bean porridge or other snacks like vegetable porridge for children. However, it doesn't happen every month... it depends on whether the midwife has some extra money or not. [Supplementary feeding] is actually very important because it can make the [mothers] and children come to Posyandu." (Cadre, 45 years old, Gowa)

\section{Discussion \\ Principal findings}

This study is the first analysis of the barriers and challenges to accessing MNCH services for Indonesian women during the COVID-19 pandemic. Much of the literature on this topic focuses solely on several factors, such as individuals, health providers, or policy factors, which affect the care-seeking behaviors in an emergency situation [20-23]. In general, our study found that MNCH services coverage dropped, especially in the first three months of the pandemic (from April to June 2020). From the qualitative interviews, this study explores multiple factors that influence women's decisions and abilities to access and receive quality $\mathrm{MNCH}$ care. Our findings indicate that fear and worry became the most determining factor that affect health service utilization during the pandemic. In addition, structural problems from unsupportive family members, financial barriers, myths, and traditional beliefs, geographical and transportation barriers, and uneven distribution of health facilities and health staff posed persistent barriers to maintaining the MNCH care in Indonesia. However, this study also found that adequate awareness of the importance of $\mathrm{MNCH}$ care among women becomes the push factor that strengthens the resilience of $\mathrm{MNCH}$ services amidst the pandemic.

\section{Individual factors}

Our findings show that the decrease in MNCH services coverage is significantly influenced by women's fear to visit health care services during the COVID-19 pandemic. The fear often causes the women to delay or stop the $\mathrm{MNCH}$ care for them or their children. This finding is consistent with other studies in developing countries which reported that fear of COVID-19 contraction influence women's decision to visit health services [21-24]. In Northeast Ethiopia, disruption of ANC services was $87 \%$ associated with the fear of coronavirus among women [23]. Our study found that fear of COVID-19 was not only related to the virus's contraction but also the fear of having COVID-19 test when visiting health facilities. For pregnant women, the fear of COVID-19 contraction may be caused by the unclear clinical impact of the virus on neonates [25]. Whereas the fear of getting tested may have been influenced by the stigma of COVID-19 patients and reduced opportunities to earn a living [26].

Aside from the fear of COVID-19, care-seeking behaviors during the pandemic are also affected by women's knowledge and awareness of the importance of the services. In this study, we found that some women had limited understanding of the urgency of MNCH services, while others already had adequate awareness about the importance of receiving the services. Women who did not understand the urgency of MNCH care will not seek any services during the pandemic. This could be addressed as persistent barriers, which had occurred before the pandemic but had a direct influence on the resilient of the $\mathrm{MNCH}$ services during the pandemic. However, when women had already had an adequate understanding of the services, they will keep seeking the services despite fear of COVID-19 or limited availability of providers during an emergency situation.

\section{Interpersonal factors}

Previous research has established that family members play an important role in influencing women's decision to utilize MNCH services [27-31]. We found that during the COVID-19 pandemic, women's extended families often discourage women to visit health service providers due to fear of COVID-19 contraction. The fear of COVID-19 among people in Indonesia is not only caused by the considerable increase in COVID-19 cases but also hoaxes and misinformation [32, 33]. Thus, when women have low decision-making autonomy in the household regarding the use of MNCH service [34], they tend to follow instructions from family members, including the prohibition to visit health facilities during the pandemic.

The current study found that family members provide unnecessary supports which burden women to visit health services. We found that in Manggarai Barat, women were overburdened to visit health providers as they need to be accompanied by their extended families. Moreover, we also found that family members, especially the elderly in the family, tend to influence women to give birth to TBAs. These results reflect those of Musadad et al. [31] who also found that parents and parents-in-law had considerable power in influencing women's decision of their MNCH care. Suryawati [30] explained that husbands, parents, and parents' in law play a significant role in giving advice and opinions related to $\mathrm{MNCH}$ care, including treatment for medical problems and the birthing process.

Another important finding from interpersonal factors is that financial barriers still hinder women in Indonesia from receiving quality $\mathrm{MNCH}$ care. In this research, women reported that they or their husbands lost jobs during the pandemic which impacted in reduction of family income. This situation forced women to delay their visits to health providers. Those who still utilize the services had to lend money from their friends or family. The COVID-19 pandemic had an enormous impact on the economic situation in Indonesia. Restriction policy had caused a reduction in communities' activities and incomes which, therefore, lead to an increase in the poverty rate $[35,36]$. This result corroborates the findings of the previous work in the relationship of poverty and $\mathrm{MNCH}$ 
services utilization in Indonesia. Women from poor households are less likely to receive quality ANC and other MNCH services compared to women from wealthy households $[37,38]$.

Despite Gol's attempts to decrease financial burdens by introducing Jaminan Kesehatan Nasional (Indonesia's National Health Insurance) since 2014, we found that the program was ineffective in remote areas. While the Jaminan Kesehatan Nasional covers the MNCH services' costs, women in remote areas still had to bear other out-of-pocket payments such as transportation and accommodation costs. Some research had reported that women who lived in Eastern Indonesia were less likely to have at least four times of ANC and institutional birth even after the introduction of Jaminan Kesehatan Nasional [39, 40].

\section{Community factors}

Participants in our study discussed that they still follow certain norms and cultural practices related to pregnancy, postpartum, and childcaring. Even though most practices related to religious traditions do not bring harm to women and children, several local traditions include the prohibition to get out of the house and to consume certain types of fruits and vegetables. The latter practices become complicating factors that inhibit the government's effort to reduce maternal and child mortality. This finding is consistent with previous inquiries which reported that some areas in Indonesia had unique traditions and norms during pregnancy and postnatal period, especially among indigenous communities [9, 41-44]. Various cultural practices during pregnancy and postpartum periods among women in Indonesia suggest that interventions that aimed to increase health-seeking behaviors should be sensitive to these practices [44]. Engaging traditional and religious champions in $\mathrm{MNCH}$ care interventions are reported as a sustainable approach to increase good practices in $\mathrm{MNCH}$ care in the community [45].

The study found that transportation and geographical barriers become important factors that inhibit women to access health facilities in Gowa and Manggarai Barat. Limited transportation services and poor road infrastructure in isolated areas cause a delay to health facilities both for women and health workers [46]. As family and community had concerns about the women's and children's safety when accessing health facilities, they often advise the women to seek help from TBAs [46]. Various programs and interventions which aim to reduce maternal and child mortalities so far had not yet been able to increase the quality of $\mathrm{MNCH}$. This study suggests that interventions that objectives to reduce maternal and child mortality should be holistic and involve multiple stakeholders from various backgrounds, not solely from health sectors [47].

\section{Organizational factors}

Inequality distribution of health resources exacerbates the efforts to maintain the MNCH services during the COVID-19 pandemic. Home visits methods adopted by many countries during the pandemic could not be effectively executed due to a shortage in health staff. Moreover, health workers also experienced an increase in workload and working time. This finding is similar to other research in LMIC which reported that women did not receive routine home visits during the pandemic due to the limited number of health workers [22]. Increasing workload and limited quantities of PPE for health workers were also occurred in other developing countries [21]. Maldistribution of health facilities and its relation to ineffective health services have been discussed in many pieces of literature from Indonesia $[9,48,49]$. The Gol has already implemented many policies related to the distribution of health resources, among others decentralization policy, deployment, planning the health placement based on the ratio of population, and permission of dual practices [48]. Nevertheless, each policy had its drawbacks which resulted in ineffective implementation. For example, insufficient incentives for the village's midwife [50], or difficulty in developing health-related community collaboration with the community [51]. While this study suggests the Gol to continue to improve equality distribution of health resources across Indonesia, another study recommends that the quality of the health personnel should also be improved by evaluating the accreditation and standardization of health workers' educational institutions [48].

This study also found issues in pharmaceutical and medical tools distributions. Some issues have occurred before the COVID-19 pandemic, while others happened during the pandemic. In Gowa and Manggarai Barat, we found that certain types of medical devices, such as ultrasonography tools and blood test kits, were not always available in all health facilities so that women need to travel farther to access those services. This finding is very different from developed countries where the government provides pregnant women with personal blood pressure machines and urinalysis sticks [52]. In Sidoarjo, although we did not find any issue regarding the unavailability of certain types of medical tools, participants reported a longer time to receive results about the COVID19 PCR test due to the minimum number of reagents and long queue. Hendarwan et al. [53] explained that long procurement time and limited capacity of human resources created a delay in producing the test results.

To sustain the $\mathrm{MNCH}$ services during the pandemic, local health workers were found to adopt innovative approaches such as home visits and using virtual consultation services in antenatal care. This finding was also reported by Townsend et al. [54] which found an increase in online ANC practices during the pandemic. However, as mentioned above, the limited number of health staff, increasing working load, and women's awareness of the importance of MNCH services influence the effectiveness of the home visits and online teleconsultation. Moreover, comfortability, mistrust about the services, and digital divide become challenges to effectively implement virtual health care [55]

\section{Policy factors}

An important finding in our study is that the Gol had a rapid response in providing guidelines about conducting safe $\mathrm{MNCH}$ care during the pandemic despite its challenging implementation. To strengthen the resilience of $\mathrm{MNCH}$ services during the pandemic, local health workers require appropriate guidelines to implement safe care. Our findings highlight that the Gol had rapidly developed, at least, three handbooks related to establishing MNCH care during the pandemic. However, the handbooks were considered as 'one size fits all' which does not take into account different socioeconomic statuses, digital gaps, and uneven distribution of health resources in disadvantaged regions. As a consequence, considerable reduction of MNCH services was unavoidable, especially in

Page 12/17 
areas with minimum resources. Ahmed et al. [20] reported that such 'one size fits all' responses were occurring globally. The policy was centered on tight restrictions on community mobilization to the effort of maintaining essential health services. In the decentralization era, the local governments in Indonesia were expected to innovatively develop and adopt appropriate approaches. However limited social capacity and resources, again, inhibit the local governments and health personnel to build resilient MNCH care during the COVID-19 pandemic.

\section{Conclusion}

The study showed that multi-faceted factors (individual, interpersonal, community, organizational, and policy) had a considerable role in the implementation of $\mathrm{MNCH}$ services during the pandemic in Indonesia. Persistent barriers from cultural beliefs, transportation, and geographical barriers, household financial problems, and inequity distribution of health resources continue becoming a drawback in developing resilient $\mathrm{MNCH}$ care in an emergency situation. A multistakeholder approach, as well as a unique policy based on local context, are required to support local health workers to maintain the needed services in a volatile situation.

\section{Abbreviations}

MNCH: Maternal Neonatal and Child Health; SEM: Socio-Ecological Model; Sustainable Development Goals (SDGs); MMR: Maternal Mortality Rate; ANC4+: fourth antenatal care; PNC: Postnatal care; Gol: Government of Indonesia; PSBB: Large Social Restriction Policy; PPKM: Policy for Enforcement of Restrictions on Community Activities; Puskesmas: Public Health Center; DHO: District Health Office; RA: Research Assistant; FGD: Focus Group Discussion; TBA: Traditional Birth Attendant; USG: Ultrasonography; Posyandu: Integrated health service post; PCR: Polymerase Chain Reaction; JKN: National Health Insurance; BPJS Kesehatan: Health care and Social Security Agency; PPE: Personal Protective Equipment.

\section{Declarations}

\section{Acknowledgements}

We are grateful to all the study participants and the Indonesian Government for approving the study. We thank all the research assistants involved in this study.

\section{Funding}

This work was supported by the Knowledge Sector Initiative, an Australia-Indonesia partnership. Grant number: 1301001-G-2018-001. The funding body has no role either in the design of the study or in the collection, analysis, interpretation of data, and in writing of the manuscript.

\section{Authors' contribution}

NSS, RKD, MDA contributed to the study design, data collection process, data analysis, data interpretation, and preparation of the manuscript; NT oversaw the study design, data analysis, and preparation of the manuscript. All authors reviewed the final manuscript prior to submission.

\section{Availability of data and materials}

The $\mathrm{MNCH}$ routine data set and qualitative datasets generated and analyzed during the study are not publicly available due to information that could compromise research participants' privacy/consent but are available from the corresponding author on reasonable request.

\section{Ethics approval and consent to participate}

Ethics approval for the study was granted by the Ethical Review Committee of Atma Jaya Catholic University (Ref No. 0024A/III/LPPM-PM.10.05/01/2021). All study methods were carried out in accordance with relevant guidelines and regulations. Permission to carry out the study was granted by Directorate General of Politics and General Government, the Ministry of Home Affairs Republic of Indonesia. Informed consents were read to the participants by the researcher in Bahasa Indonesia. Due to COVID-19 case increases the data collection was conducted by phone. We read the consent form to all participants and received recorded verbal agreements. This method was approved by Ethical Review Committee of Atma Jaya Catholic University. All participants were aware they could withdraw from the study at any given time if they changed their minds.

\section{Consent for publication}

Not Applicable

\section{Competing interest}

The authors declare that they have no competing interests. 


\section{References}

1. World Health Organization. Targets and Strategies for Ending Preventable Maternal Mortality. 2014.

http://apps.who.int/iris/bitstream/handle/10665/130776/WHO_RHR_14.21_eng.pdf?sequence=1. Accessed 23 Sep 2021.

2. World Bank. Maternal mortality ratio (modeled estimate, per 100,000 live births) - Indonesia. 2019. https://data.worldbank.org/indicator/SH.STA.MMRT. Accessed 23 Sep 2021.

3. World Bank. Mortality rate, neonatal (per 1,000 live births) - Indonesia. 2019. https://data.worldbank.org/indicator/SH.DYN.NMRT?locations=ID. Accessed 23 Sep 2021.

4. World Bank. Mortality rate, under-5 (per 1,000 live births) - Indonesia. 2019. https://data.worldbank.org/indicator/SH.DYN.MORT?locations=ID. Accessed 23 Sep 2021.

5. Badan Pusat Statistik, Badan Penelitian dan Pengembangan Kesehatan. Laporan Pelaksanaan Integrasi Susenas Maret 2019 dan SSGBI Tahun 2019. Jakarta; 2019. https://www.google.com/url?

sa=t\&rct=j\&q=\&esrc=s\&source=web\&cd=\&cad=rja\&uact=8\&ved=2ahUKEwiPxr_85pTzAhVSOisKHTKCBIMQFnoECAsQAQ\&url=https\%3A\%2F\%2Fstunting.g

6. Kementerian Kesehatan. Profil Kesehatan Indonesia. Jakarta; 2020. https://pusdatin.kemkes.go.id/resources/download/pusdatin/profil-kesehatanindonesia/Profil-Kesehatan-indonesia-2019.pdf.

7. Badan Pusat Statistik. Berita Resmi Statistik: Hasil Sensus Penduduk 2020. Jakarta; 2021.

8. UNICEF. Improving Maternal and Newborn Health Services in Eastern Indonesia: Findings from An External Review. 2017. https://www.unicef.org/indonesia/media/1801/file/Improving maternal and newborn health services in Eastern Indonesia.pdf. Accessed 23 Sep 2021.

9. Joint Committee on Reducing Maternal and Neonatal Mortality in Indonesia, Development, Security and C, Policy and Global Affairs, National Research Council, Indonesian Academy of Sciences. Reducing Maternal and Neonatal Mortality in Indonesia: Saving Lives, Saving the Future. 2013. https://www.ncbi.nlm.nih.gov/books/NBK201708/. Accessed 23 Sep 2021.

10. Tosepu R, Effendy DS, Ahmad LOAI. The First Confirmed Cases of COVID-19 in Indonesian Citizens. Public Heal Indones. 2020;6:70-1. http://stikbar.org/ycabpublisher/index.php/PHI/article/view/337/pdf.

11. Muhyiddin, Nugroho H. A Year of COVID-19: A Long Road to Recovert and Acceleration of Indonesia's Development. J Perenc Pembang. 2021;5. doi:10.36574/jpp.v5i1.

12. Delamou A, Ayadi AME, Sidibe S, Delvaux T, Camara BS, Sandouno SD, et al. Effect of Ebola virus disease on maternal and child health services in Guinea: a retrospective observational cohort study. Lancet Glob Heal. 2017;5:e448-57. doi:10.1016/S2214-109X(17)30078-5.

13. Gizelis T-I, Karim S, Ostby G, Urdal H. Maternal Health Care in the Time of Ebola: A Mixed-Method Exploration of the Impact of the Epidemic on Delivery Services in Monrovia. World Dev. 2017;20.

14. Kompas.com. 9 Kabupaten dan 1 Kota Masuk Zona Merah Covid-19, Pemprov NTT Belum Berlakukan PSBB. 2020. https://regional.kompas.com/read/2020/05/19/16553731/9-kabupaten-dan-1-kota-masuk-zona-merah-covid-19-pemprov-ntt-belum.

15. Reininger BM, Barroso CS, Mitchell-Bennett L, Chavez M, Fernandez ME, Cantu E, et al. Socio-ecological influences on health-care access and navigation among persons of Mexican descent living on the U.S./Mexico border. J Immigr Minor Heal. 2014;16:218-28. doi:10.1007/s10903-012-9714-3.

16. Yakob B, Ncama BP. A socio-ecological perspective of access to and acceptability of HIV/AIDS treatment and care services: a qualitative case study research. BMC Public Health. 2016;16:155. doi:10.1186/s12889-016-2830-6.

17. Dinas Kesehatan Kabupaten Sidoarjo. Profil Kesehatan Tahun 2020. Sidoarjo; 2021.

18. Dinas Kesehatan Provinsi Sulawesi Selatan. Profil Kesehatan Provinsi Sulawesi Selatan 2017 (Tabel). 2017. http://dinkes.sulselprov.go.id/uploads/info/PK-2017.pdf.

19. Badan Pusat Statistik. Profil Kesehatan Kabupaten Manggarai Barat, 2019. 2019. https://sirusa.bps.go.id/sirusa/index.php/sektoral/pdf? $k d=12674 \&$ th=2019. Accessed 4 Oct 2021.

20. Ahmed T, Rahman AE, Amole TG, Galadanci H, Matjila M, Soma-Pillay P, et al. The effect of COVID-19 on maternal newborn and child health (MNCH) services in Bangladesh, Nigeria and South Africa: call for a contextualised pandemic response in LMICs. Int J Equity Health. 2021;20:77. doi:10.1186/s12939-021-01414-5.

21. Yihun B, Tiruneh G, Tebekaw Y, Bekele B, Emway D, Fesseha N, et al. Stress and anxiety among late adulthood in Indonesia during COVID-19 outbreak. 2020;6. doi:https://doi.org/10.29210/02020612.

22. Temesgen K, Workie A, Dilnessa T, Getaneh E. The impact of COVID-19 infection on maternal and reproductive health care services in governmental health institutions of Dessie town, North-East Ethiopia, 2020 G.C. unpublished. 2020.

23. Tadesse E. Antenatal Care Service Utilization of Pregnant Women Attending Antenatal Care in Public Hospitals During the COVID-19 Pandemic Period. Int J Womens Health. 2020;12:1181-8.

24. Goyal M, Singh P, Singh K, Shekhar S, Agrawal N, Misra S. The effect of the COVID-19 pandemic on maternal health due to delay in seeking health care: Experience from a tertiary center. Int J Gynaecol Obstet Off organ Int Fed Gynaecol Obstet. 2021;152:231-5.

25. Liang H, Acharya G. Novel corona virus disease (COVID-19) in pregnancy: What clinical recommendations to follow? Acta Obs Gynecol Scand. 2020;99:439-42. https://obgyn.onlinelibrary.wiley.com/doi/epdf/10.1111/aogs.13836?src=getftr.

26. Atika S. Stigma, precarity deter Indonesians from getting tested for COVID-19. 2020. https://www.thejakartapost.com/news/2020/07/08/stigmaprecarity-deter-indonesians-from-getting-tested-for-covid-19.html. 
27. Upadhyay P, Liabsuetrakul T, Shrestha AB, Pradhan N. Influence of family members on utilization of maternal health care services among teen and adult pregnant women in Kathmandu, Nepal: A cross sectional study. Reprod Health. 2014;11:92.

28. Sakuma S, Yasuoka J, Phongluxa K, Jimba M. Determinants of continuum of care for maternal, newborn, and child health services in rural Khammouane, Lao PDR. PLoS One. 2019. doi:https://doi.org/10.1371/journal.pone.0215635.

29. Zahtamal, Restuastuti T, Chandra F. Analisis Faktor Determinan Permasalahan Pelayanan Kesehatan Ibu dan Anak. Kesmas J Kesehat Masy Nas. 2011;6:9-16.

30. Suryawati C. Faktor Sosial Budaya dalam Praktik Perawatan Kehamilan, Persalinan, dan Pasca Persalinan (Studi di Kecamatan Bangsri Kabupaten Jepara). J Promosi Kesehat Indones. 2007;2. https://media.neliti.com/media/publications/4955-ID-faktor-sosial-budaya-dalam-praktik-perawatankehamilan-persalinan-dan-pasca-pers.pdf.

31. Musadad A, Rachmalina, Rahajeng E. Pengambilan Keputusan dalam Pertolongan Persalinan di Provinsi Nusa Tenggara Timur. J Ekol Kesehat. 2003;2. https://media.neliti.com/media/publications/79484-ID-pengambilan-keputusan-dalam-pertolongan.pdf.

32. Ravelo JL. "Hoax killed my father": Indonesia's other pandemic. Inside Development. 2021. https://www.devex.com/news/hoax-killed-my-fatherindonesia-s-other-pandemic-100488. Accessed 5 Dec 2021.

33. Ifdil I, Yuca V, Yendi FM. Stress and anxiety among late adulthood in Indonesia during COVID-19 outbreak. JPPI (Jurnal Penelit Pendidik Indones. 2020;6:31.

34. Rizkianti A, Afifah T, Saptarini I, Rakhmadi MF. Women's decision-making autonomy in the household and the use of maternal health services: An Indonesian case study. Midwifery. 2020;90:102816. doi:https://doi.org/10.1016/j.midw.2020.102816.

35. Suryahadi A, Izzati R Al, Suryadarma D. Estimating the Impact of COVID-19 Outbreak on Poverty. Bull Indones Econ Stud. 2020;56.

36. Prawoto N, Purnomo EP, Zahra AA. The Impacts of Covid-19 Pandemic on Socio-Economic Mobility in Indonesia. Int J Econ Bus Adm. 2020;8.

37. Efendi F, Chen C-M, Kurniati A, Berliana SM. Determinants of utilization of antenatal care services among adolescent girls and young women in Indonesia. Women Health. 2016.

38. Nababan HY, Hasan M, Marthias T, Dhital R, Rahman A, Anwar I. Trends and inequities in use of maternal health care services in Indonesia, 1986-2012. Int J Womens Health. 2018;10:11-24.

39. Nasution SK, Mahendradhata Y, Trisnantoro L. Can a National Health Insurance Policy Increase Equity in the Utilization of Skilled Birth Attendants in Indonesia? A Secondary Analysis of the 2012 to 2016 National Socio-Economic Survey of Indonesia. Asia Pacific J Public Heal. 2020;32. doi:10.1177/1010539519892394.

40. Anindya K, Lee JT, McPake B, Wilopo SA, Millett C, Carvalho N. Impact of Indonesia's national health insurance scheme on inequality in access to maternal health services: A propensity score matched analysis. J Glob Health. 2020;10:1-12.

41. Kartika V, Agustiya RI, Kusnali A. Budaya Kehamilan dan Persalinan pada Masyarakat Baduy di Kabupaten Lebak, Tahun 2018. Bul Penelit Sist Kesehat. 2019;22.

42. Ipa M, Prasetyo DA, Kasnodihardjo K. Praktik Budaya Perawatan Dalam Kehamilan Persalinan Dan Nifas Pada Etnik Baduy Dalam. J Kesehat Reproduksi. 2016;7.

43. Ninu JJAS, Rihadi S, Tirtahusada K. Gambaran Penanganan Ibu Hamil dan Bersalin pada Suku Boti dalam Kecamatan Kie Kabupaten Timor Tengah Selatan. J Widya Med Surabaya. 2018;4.

44. Lestari W, Agustina ZA. Meta-Etnografi Budaya Persalinan Di Indonesia. J Masy Budaya. 2018;20:49-60. http://jmb.lipi.go.id/index.php/jmb/article/view/511.

45. Walker J-A, Hashim Y, Oranye N. Impact of Muslim opinion leaders' training of healthcare providers on the uptake of MNCH services in Northern Nigeria. Glob Public Health. 2019;14:200-13.

46. Tira DS. Decision Making on Family Level in Having Treatment: A Case Study of Mother and Children's health Revolution Program in East Indonesia. Int $J$ Health Sci (Qassim). 2019;3. https://media.neliti.com/media/publications/328780-decision-making-on-family-level-in-havin-030fb045.pdf.

47. Sitorus J. Upaya penurunan jumlah kematian ibu dan bayi melalui peran stakeholder. Inovasi. 2020;17.

48. Rokx C, Giles J, Satriawan E, Marzoeki P, Harimurti P, Yavuz E. New Insights into the Provision of Health Services in Indonesia: A Health Workforce Study. Washington D.C.; 2010. https://documents1.worldbank.org/curated/en/799111468038325818/pdf/538830PUB0Heal1010fficial0Use0Only1.pdf.

49. Ayuningrum VR, Febrianti VE, Khasanah AN, Kurnianto FA, Ikhsan FA. Influence of Labor Service Facility on Infant Mortality Rate in Indonesia. Maj Pembelajaran Geogr. 2019;2.

50. Ensor T, Quayyum Z, Nadjib M, Sucahya P. Level and determinants of incentives for village midwives in Indonesia. Health Policy Plan. 2009;24:26-35. doi:10.1093/heapol/czn040.

51. The National Team for the Acceleration of Poverty Reduction. Nusantara Sehat Team-based Deployment for Comprehensive Primary Health Care: How Does the Program Influence Interprofessional Collaborative Practice and the Perception of a Primary Health Care Career in Left-Behind Areas in Indonesia. Jakarta; 2020. http://tnp2k.go.id/download/99976Nusantara Sehat Team-based Deployment per 8 October 2020 (ISBN).pdf.

52. Coxon K, Turienzo CF, Kweekel L, Goodarzi B, Brigante L, Simon A, et al. The impact of the coronavirus (COVID-19) pandemic on maternity care in Europe. Midwifery. 2020;88:102779.

53. Hendarwan H, Syachroni S, Aryastami NK, Su'udi A, Susilawati MD, Despitasari M, et al. Assessing the COVID-19 diagnostic laboratory capacity in Indonesia in the early phase of the pandemic. WHO South-East Asia J Public Heal. 2020;9.

54. Townsend R, Chmielewska B, Barratt I, Kalafat E, van der Meulen J, Gurol-Urganci I, et al. Global changes in maternity care provision during the COVID-19 pandemic: A systematic review and meta-analysis. EClinicalMedicine. 2021;37. 
55. Wu H, Sun W, Huang X, Yu S, Wang H, Bi X, et al. Online Antenatal Care During the COVID-19 Pandemic: Opportunities and Challenges. J Med Internet Res. 2020;22:e19916. doi:10.2196/19916.

\section{Figures}

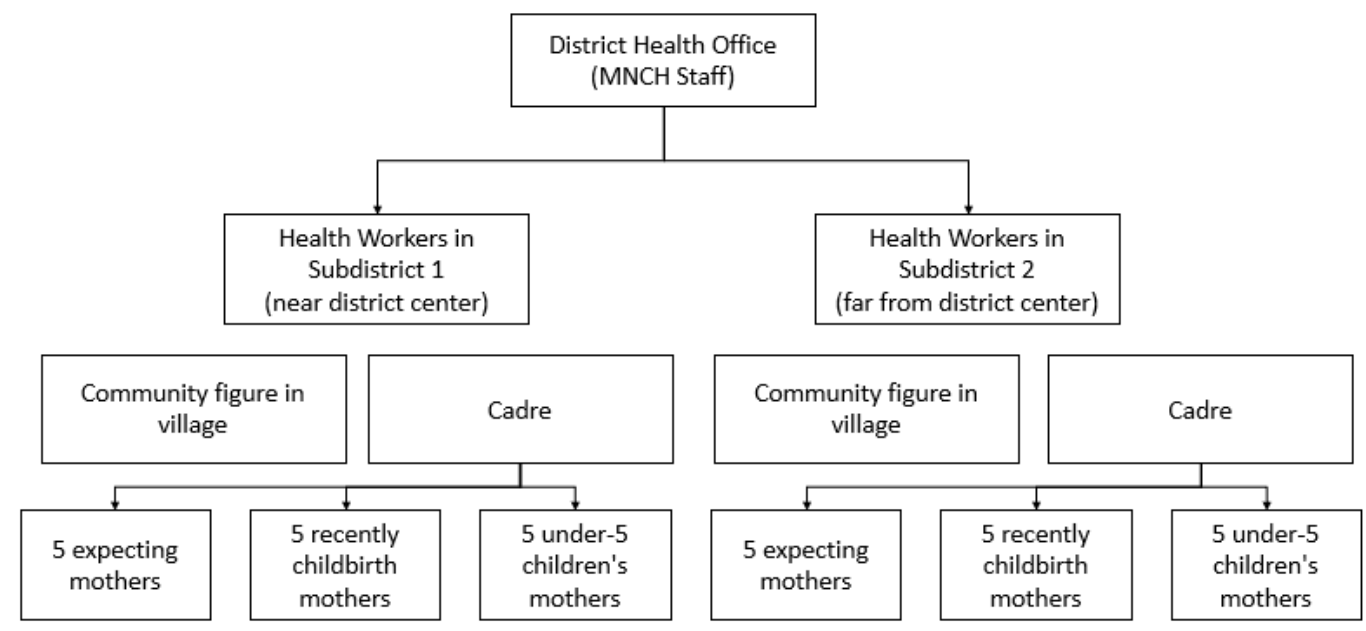

\section{Figure 1}

Snowball sampling method used in the study

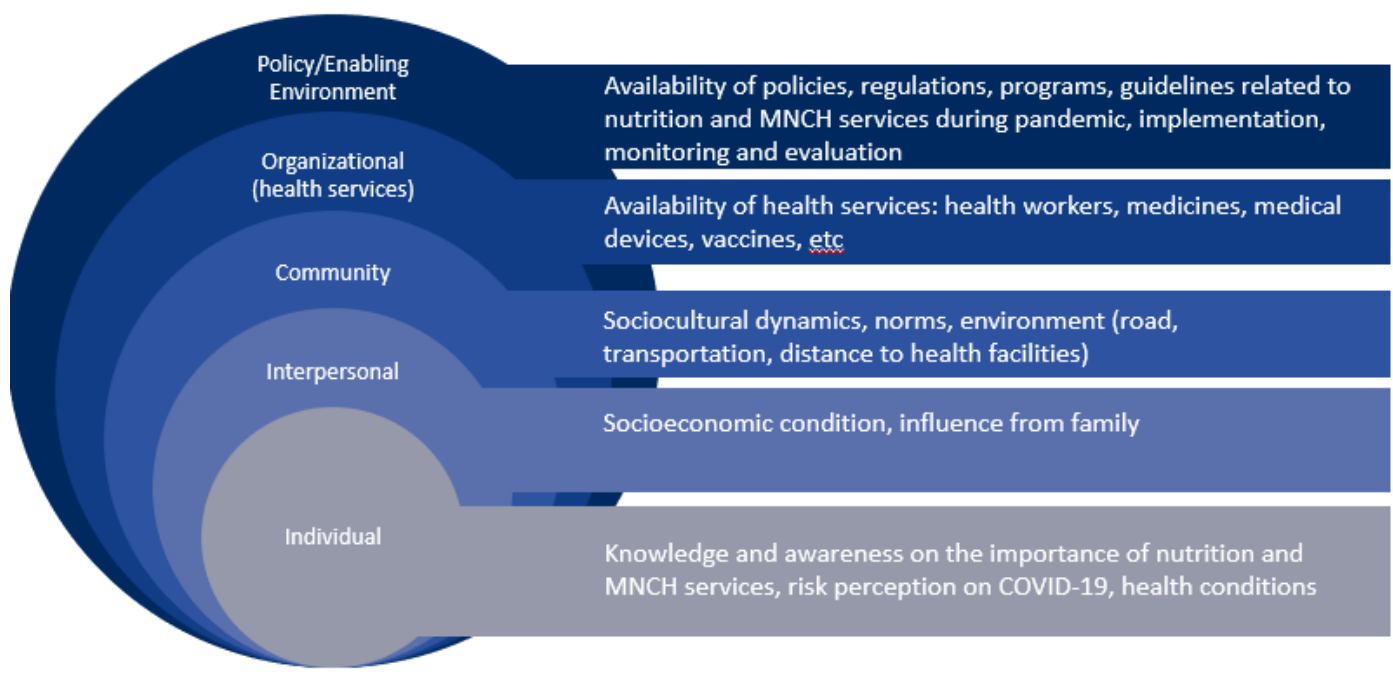

Figure 2

SEM Framework 

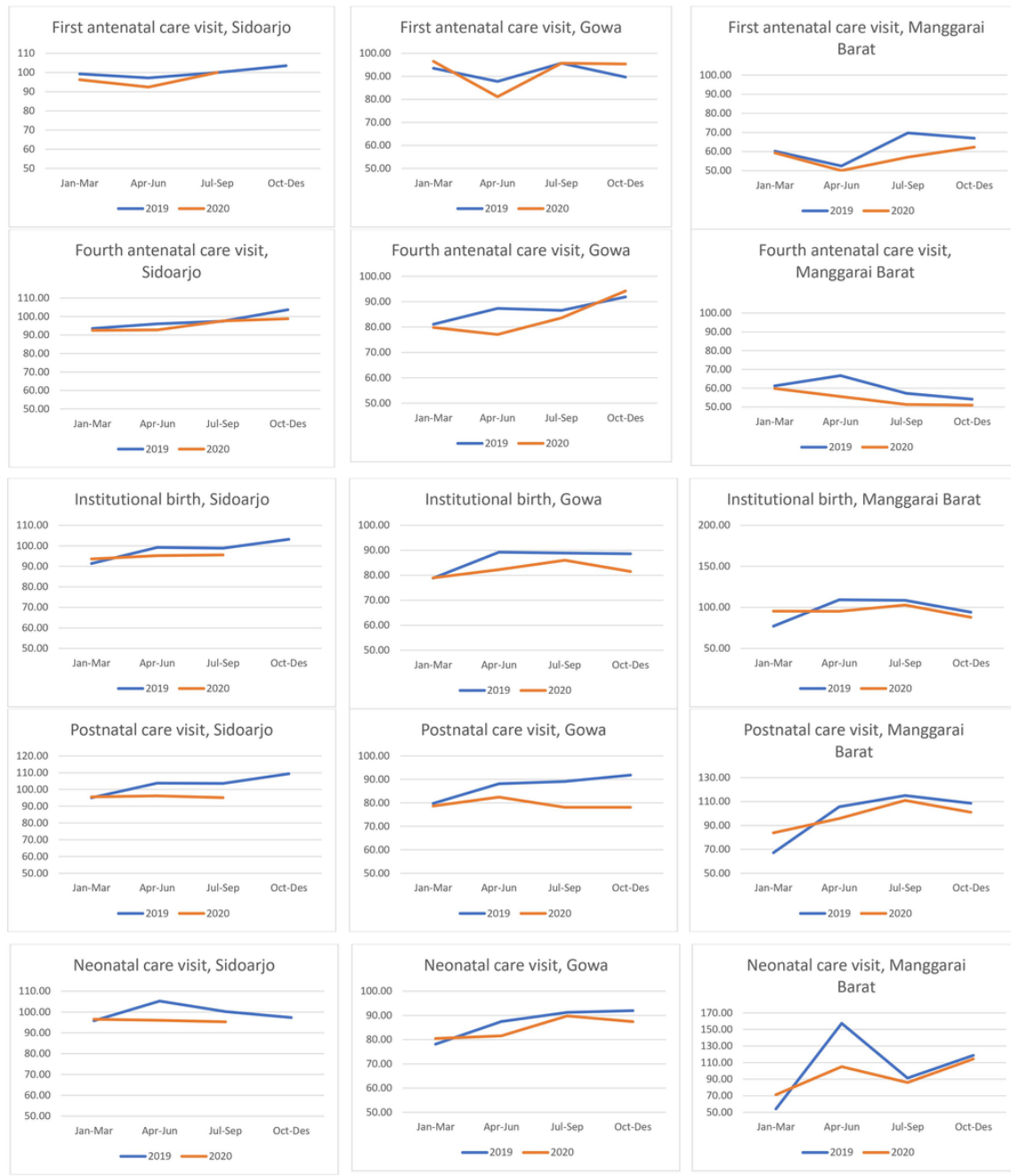

\section{Figure 3}

Monthly MNCH Services Indicators from Three Districts, 2019-2020
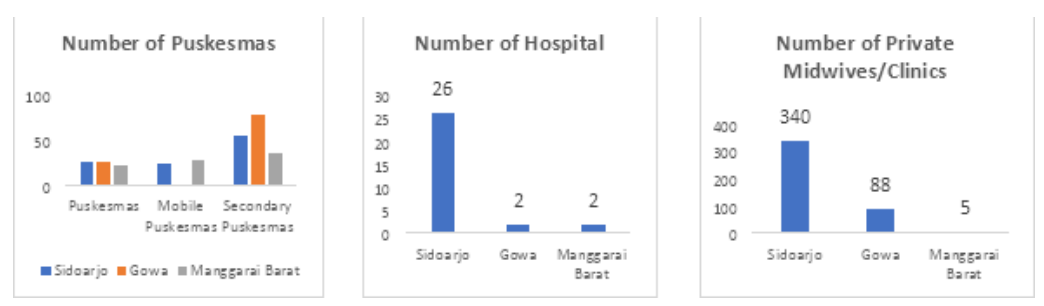

\section{Figure 4}

\section{Comparison of available MNCH services provides across districts}

Source: [17-19] 